\title{
Analisis Data Kualitatif
}

\section{Ahmad Rijali \\ UIN Antasari Banjarmasin}

\begin{abstract}
Data collection is interactive with data analysis, data collection is an integral part of data analysis activities. Data reduction is an attempt to deduce data, then sorting through data in certain conceptual units, certain categories, and certain themes. Data reduction results are processed in such a way as to look more fully in their figure. It may take the form of sketches, synopsis, matrices, and other forms; it is very necessary to facilitate the explanation and affirmation of conclusions. The process, not once, but interacts back and forth. The process of occurrence in qualitative research is very dependent on the complexity of the problems to be answered and the sharpness of the researchers' traceability in making comparisons during the data collection process. How can the data analysis process be operated? This paper will attempt to answer and describe the parts (1) understanding the meaning of data analysis, (2) analysis when collecting data; (3) data reduction; (4) data presentation; (5) drawing conclusions and verification.
\end{abstract}

Keywords: analysis; qualitative.

\section{Pendahuluan}

Sanapiah Faisal (2010) menjelaskan perbedaan dan persamaan antara penelitian kuantitatid dan kualitatif, ia memulai penjelasan tentang "tabel". "Tabel" merupakan gambaran tentang para responden setelah melewati penelitian dengan menggunakan salah satu teknik penggalian data, sebut saja teknik angket. Setelah angket terkumpul, 
biasanya dilanjutkan dengan proses editing, koding, dan tabulasi. Hasil tabulasi tersebut bisa disajikan dalam bentuk "tabel". Gambaran dalam "tabel" tersebut merupakan cerminan dari keadaan nyata yang tersebar di tengah masyarakat. Ia merupakan hasil ringkasan kenyataan para responden yang tersebar di masyarakat. Ringkasan berupa tabel itu, selanjutnya perlu ditafsirkan, dimaknakan dan disimpulkan berdasarkan perhitungan tertentu dan menggunakan angka-angka yang ada dalam tabel tersebut.

Proses dari kenyataan lapangan ke "tabel", dan berdasarkan "tabel" kemudian ditafsirkan, dimaknakan, kemudian disimpulkan juga berlangsung dalam penelitian kualitatif. Bedanya, dalam penelitian kualitatif "tabel" tersebut dianggap tercantum dalam kenyataan sehari-hari di masyarakat, bukan tercantum di atas kertas (seperti dalam penlitian kuantitatif).

Kejadian, tindakan, peristiwa, keadaan yang tersebar di masyarakat merupakan tabel-tabel konkret yang menunggu untuk ditafsirkan dan bagaimana makna di balik tabel itu diburu dan dikejar dalam tradisi penelitian kualitatif.

Proses kerja dalam penelitian kuantitatif dimulai dari perumusan masalah, kemudian perumusan hipotesis, penyusunan instrumen pengumpulan data, selanjutnya kegiatan pengumpulan data, baru dilakukan analisis data, dan akhirnya penulisan laporan penelitian. Proses kerja itu tidak boleh tertukar, harus berurutan secara linier.

Dalam penelitian kualitatif, konseptualisasi, kategorisasi, dan deskripsi dikembangkan atas dasar "kejadian" yang diperoleh ketika kegiatan lapangan berlangsung. Karenanya, antara kegiatan pengumpulan data dan analisis data tidak mungkin dipisahkan satu sama lain. Keduanya berlangsung secara simultan, prosesnya 
berbentuk siklus dan interaktif, bukan linier. Miles dan Huberman (1992:20) menggambarkan proses analisis data penelitian kualitatif sebagai berikut.

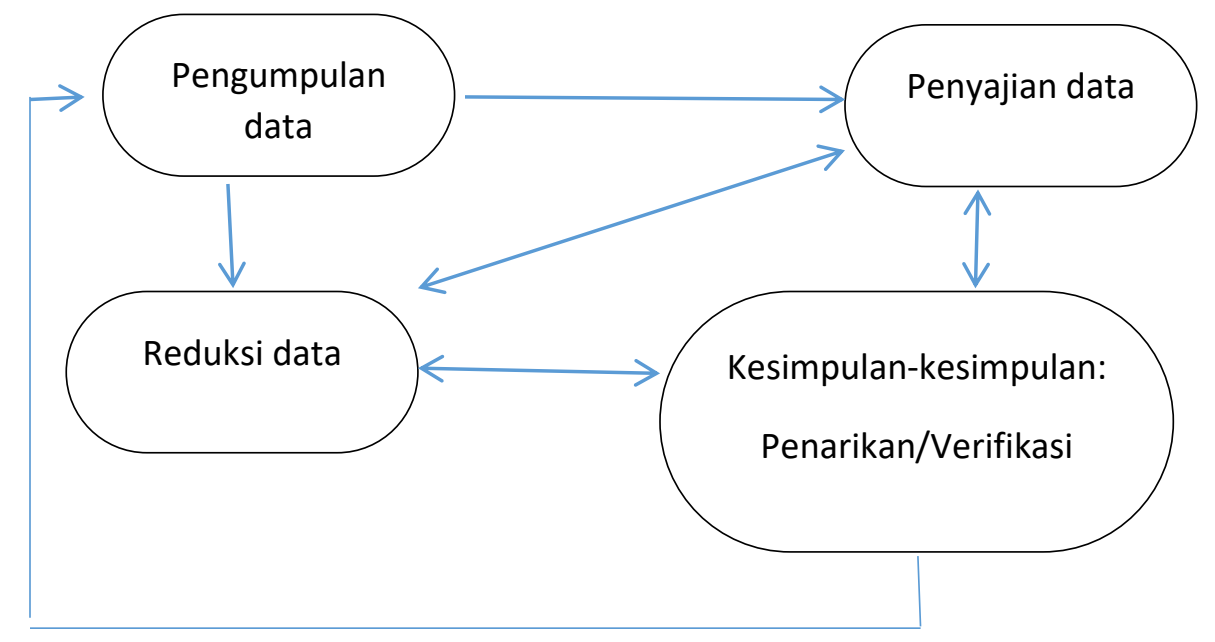

Gambar 1 Proses Analisis Data Penelitian Kualitatif

Gambar tersebut memperlihatkan sifat interaktif pengumpulan data dengan analisis data, pengumpulan data merupakan bagian integral dari kegiatan analisis data. Reduksi data adalah upaya menyimpulkan data, kemudian memilah-milah data dalam satuan konsep tertentu, kategori tertentu, dan tema tertentu.

Hasil reduksi data diolah sedemikian rupa supaya terlihat sosoknya secara lebih utuh. Ia boleh berbentuk sketsa, sinopsis, matriks, dan bentuk lainnya; itu sangat diperlukan untuk memudahkan pemaparan dan penegasan kesimpulan. Prosesnya, tidak sekali jadi, melainkan berinteraksi secara bolak balik. Seberapa kali bolak balik terjadi dalam penelitian? Tentu, sangat tergantung pada kompleksitas permasalahan yang hendak dijawab dan ketajaman daya lacak si peneliti dalam melakukan komparasi ketika proses pengumpulan data. Bagaimana proses analisis data itu dapat dioperasikan? Makalah ini akan berupaya menjawab dan menguraikan 
bagian-bagian (1) memahami pengertian analisis data, (2) analisis ketika pengumpulan data; (3) reduksi data; (4) penyajian data; (5) penarikan kesimpulan dan verifikasi.

\section{Pembahasan}

\section{Memahami Pengertian Analisis Data}

Noeng Muhadjir (1998: 104) mengemukakan pengertian analisis data sebagai "upaya mencari dan menata secara sistematis catatan hasil observasi, wawancara, dan lainnya untuk meningkatkan pemahaman peneliti tentang kasus yang diteliti dan menyajikannya sebagai temuan bagi orang lain. Sedangkan untuk meningkatkan pemahaman tersebut analisis perlu dilanjutkan dengan berupaya mencari makna."

Dari pengertian itu, tersirat beberapa hal yang perlu digarisbawahi, yaitu (a) upaya mencari data adalah proses lapangan dengan berbagai persiapan pralapangan tentunya, (b) menata secara sistematis hasil temuan di lapangan, (c) menyajikan temuan lapangan, (d) mencari makna, pencarian makna secara terus menerus sampai tidak ada lagi makna lain yang memalingkannya, di sini perlunya peningkatan pemahaman bagi peneliti terhadap kejadian atau kasus yang terjadi. Pengertian seperti itu, tampaknya searah dengan pendapat Bogdan, yaitu: "Data analysis is the process of systematically searching and arranging the interview transcripts, fieldnotes, and other materials that you accumulate to increase your own understanding of them and to enable you to present what you have discovered to others" (Sugiono, 2007:427). Yang perlu digarisbawahi dari analisis data menurut Bogdan, selain yang dikemukakan Noeng Muhadjir ialah field notes atau catatan lapangan, masalah ini akan diuraikan dalam penjelsan khusus. 
Bogdan, sebetulnya, membedakan analisis selama di lapangan dan analisis pascalapangan. Analisis selama di lapangan disebutkan oleh Bogdan antara lain: (1) mempersempit fokus studi (harus diingat mempersempit fokus studi yang berarti holistik yang fenomenologik; tidak sama dengan menspesifikasi objek studi yang berpikir secara parsial ala positivistik), (2) menetapkan tipe studi, apakah penelitian sejarah, telaah taksonomi, genetik, dan lain-lain, (3) mengembangkan secara terus-menerus pertanyaan analitik. Selama di lapangan peneliti bertanya, mencari jawab, dan menganalisisnya, selanjutnya mengembangkan pertanyaan baru untuk memperoleh jawaban, begitu dilakukan terus menerus, maka penelitian itu dapat mengarah kepada grounded theory, (4) menulis komentar yang dilakukan oleh peneliti sendiri, (5) upaya penjajagan ide dan tema penelitian pada subjek responden sebagai analisis penjajagan (langkah ini tentu saja harus dilakukan pada tahap-tahap awal penelitian), (6) membaca kembali kepustakaan yang relevan selama di lapangan (cara ini membantu untuk mengembangkan ide penulisan, tetapi ada bahayanya; peneliti dapat terpengaruh pada ide, konsep, atau model yang dipakai penulis buku), (7) menggunakan metafora dan analogi konsep-konsep. Sedangkan analisis pascalapangan adalah mengambil istirahat beberapa lama; dan siap kembali bekerja dengan pikiran yang segar (Muhadjir, 1998: 104-105).

Jika dicermati pengertian analisis data tersebut, maka dapat dipahami bahwa kegiatan analisis data kualitatif menyatu dengan aktivitas pengumpulan data, reduksi data, penyajian data, dan penyimpulan hasil penelitian.

\section{Analisis Ketika Pengumpulan Data}

Pengumpulan data di lapangan tentu berkaitan dengan teknik penggalian data, dan ia berkaitan pula dengan sumber dan jenis data, 
setidaknya sumber data dalam penelitian kualitatif berupa: (1) katakata dan (2) tindakan, selebihnya adalah data tambahan seperti dokumen atau sumber data tertulis, foto, dan statistik. Kata-kata dan tindakan orang-orang yang diamati atau diwawancarai merupakan sumber data utama. Sumber data utama dicatat melalui catatan tertulis atau melalui perekaman video/audio tapes, pengambilan foto, atau film. Sedangkan sumber data tambahan yang berasal dari sumber tertulis dapat dibagi atas sumber buku dan majalah ilmiah, sumber dari arsip, dokumen pribadi, dan dokumen resmi (Moleong, 2000:112113).

Oleh karena itu, catatan lapangan tampaknya sangat perlu untuk digunakan dalam pengumpulan data selama di lapangan, ia merupakan instrumen utama yang melekat pada beragam teknik pengumpulan data kualitatif. Bentuk catatan lapangan ini: (1) catatan fakta: data kualitatif hasil pengamatan dan wawancara dalam bentuk uraian rinci maupun kutipan langsung, (2) catatan teori: hasil analisis peneliti di lapangan untuk menyimpulkan struktur masyarakat yang ditelitinya, serta merumuskan hubungan antara topik-topik (variabel) penting penelitiannya secara induktif sesuai fakta-fakta di lapangan, (3) catatan metodologis: pengalaman peneliti ketika berupaya menerapkan metode kualitatif di lapangan. Isi masing-masing catatan ada dua; pertama catatan deskriptif: berisi bagian utama, kedua catatan reflektif/memo: berisi kritik terhadap catatan deskriptif.

Selain itu, analisis data kualitatif dapat berupa pemeriksaan keabsahan data berdasar kriteria tertentu yaitu atas dasar keterpercayaan (kridebilitas), keteralihan, kebergantungan, dan kepastian (penemuan betul-betul berasal dari data, tidak menonjolkan pengetahuan peneliti dalam konseptualisasi), hal ini disebutkan beberapa teknik pemeriksaan keabsahan data oleh Moleong 
(2000:175-188): (1) perpanjangan keikutsertaan di lapangan penelitian, (2) ketekunan pengamatan, (3) triangulasi (dengan sumber: membandingkan dan mengecek balik derajat kepercayaan suatu informasi yang diperoleh melalui waktu dan alat yang berbeda; dengan metode: pengecekan derajat keterpercayaan penemuan dan kepercayaan teknik pengumpulan data; dengan penyidik: membandingkan hasil analis yang satu dengan analis yang lain; dengan teori, (4) pemeriksaan sejawat melalui diskusi, (5) analisis kasus negatif, (6) kecukupan referensial, (7) pengecekan anggota( baik secara formal maupun informal berkenaan pengecekan kategori analitis, penafsiran, dan kesimpulan, (8) uraian rinci (terutama dalam membangun keteralihan; yaitu uraian seteliti dan secermat mungkin yang menggambarkan konteks tempat penelitian yang menjadi focus pengamatan), (9) auditing (dilakukan berdasarkan kriteria kepastian data mentah, data yang sudah direduksi, hasil sintesis, catatan proses, bahan catatan pribadi atau refleksi, motivasi, harapan, dan ramalan)

Contoh tentang analisis data ketika pengumpulan data di lapangan dapat dilihat melalui karya Alfani Daud, ia mengemukakan hasil penelitian kualitatifnya, untuk mencapai gelar Doktor, yang sudah dibukukan berjudul: "Islam dan Masyarakat Banjar Deskripsi dan Analisa Kebudayaan Banjar", dalam pembahasan bacaan-bacaan dan saji, Alfani Daud mengamati bacaan orang Banjar ketika bersaji yang disebut mamangan atau mantra, laporan tentang itu (menggunakan metode observasi) dapat dikutip sebagai berikut.

... Pada Aruh Tahun di Akar Bagantung pada tanggal 15 Desember 1980 (8 Safar $1400 \mathrm{H}$ ) penulis dan seorang teman, yang hadir sebagai undangan khusus, diperkenalkan pada tokoh gaib, sebagai seorang tokoh 
terkemuka masyarakat Banjar. Pada aruh manyanggar bulan Safar tahun berikutnya, pada pertunjukan wayang malam hari menjelang upacara bersaji siang harinya, yang secara kebetulan penulis hadiri, Semar, yang memainkan peranan sebagai tokoh yang mewakili bubuhan memperingatkan Batara Kala agar memelihara anggotaanggota kerabat dan keluarga-keluarga lain yang dianggap kerabat dari gangguan anak buah Batara Kala yang nakalnakal. Keluarga-keluarga yang dianggap kerabat ini diperinci satu per satu tampaknya karena berjasa terhadap bubuhan., khususnya membantu pelaksanaan upacara aruh. Mamangan yang konkret secara utuh tidak berhasil penulis rekam, namun penulis yakin tidaklah begitu jauh menyimpang dari yang telah berhasil direkam oleh Mansyah (1980) (Daud, 1997:352-353).

Dari kutipan tersebut, terlihat (1) situs penelitian atau lokasi penelitian (tentu dengan berbagai pertimbangan) memilih Desa Akar Bagantung Kabupaten Banjar dan Barikin Kabupaten Hulu Sungai Tengah, (2) lamanya penelitian, satu tahun untuk tema bacan-bacaan dan saji dalam upacara aruh, (3) memakai hasil rekaman orang lain yang diyakini kebenarannya (karena telah pernah mendengar dan hadir dalam upacara aruh), (4) hubungan antara peneliti dan responden, peneliti telah dianggap sebagai in group dan dihormati sebagai tokoh orang Banjar. Artinya peneliti telah lama membina hubungan baik dengan responden dan telah membuat raport.

Lebih jelas lagi proses lapangan ternyata cukup lama, pada bagian awal Alfani Daud (1997:14-20) menulis (sudah diringkas): (1) 
Kampung Dalam Pagar dengan penduduk subsuku Banjar (Kuala), pada tahun 1975 ada seorang ahli sejarah memperkenalkan kampung Dalam Pagar di Martapura, kemudian tahun 1977 penulis berdiam di kampung ini selama empat bulan, tinggal persis di lokasi pemukiman Syekh Muhammad Arsyad dan keluarganya, di situ beliau mendirikan pengajian pada waktu hidupnya pada akhir abad ke-18 sampai permulaan abad ke-19, selama menetap di sana penulis berhasil membina hubungan, bahkan kampung bagian lain di sekitar Dalam Pagar, termasuk kampung Akar Bagantung. Tahun 1979 sampai 1982 telah melakukan wawancara dan diskusi-diskusi dengan berbagai informan di sana, (2) Kampung Labuhan, kantong pemukiman suku Dayak Bukit yang tinggal di tengah-tengah pemukiman Islam, pada mulanya penulis beranggapan orang-orang subsuku Pahuluan adalah satu asal usul dengan suku Dayak Bukit dan kampong tersebut sedang dalam proses pengislaman, anggapan ini ternyata tidak seluruhnya benar. Kampung Labuhan konon juga merupakan orientasi ilmu-ilmu gaib seperti kampung Dalam Pagar. Selama waktu penulis menetap di lapangan dan waktu-waktu sesudahnya penulis berhasil mengamati berbagai kegiatan berupacara yang terjadi dalam masyarakat, berbagai praktik pengobatan dan peramalan, dan setelah berbagai diskusi, penulis berhasil mengidentifikasi kepercayaan yang menjadi dasarnya. Berbagai kegiatan berupacara terpaksa diamati di luar waktu penulis tinggal di lapangan, dan kegiatan lainnya, khususnya ketika penulis sadar menemukan kesulitan mengamati kegiatan yang sejenis, pendekatan dilakukan juga dengan wawancara dan diskusi-diskusi. Berkenaan dengan berupacara bersaji, penulis melakukan pengamatan jauh di luar lokasi penelitian demi memperoleh bahan perbandingan. 
Kekuatan karakter analisis lapangan cukup kuat dalam ringkasan tersebut, mulai dari penetapan lokasi penelitian, dugaandugaan, pertanyaan dan diskusi, komparasi, dan observasi lapangan berjalan mengalir.

Secara alami, tentu metode observasi tidak hanya dilakukan terhadap realitas atau fakta lapangan dalam kenyataan-kenyataan berupacara yang terlihat, tetapi juga terhadap yang terdengar. "Berbagai macam ungkapan atau pertanyaan yang terlontar dalam percakapan sehari-hari juga termasuk bagian dari kenyataan yang dapat diobservasi, observasinya melalui indera pendengaran. Malah sejumlah suasana terasakan, seperti rasa tercekam, rasa suka ria, dan semacamnya juga termasuk bagian dari kenyataan yang dapat diobservasi" (Faisal, 2010:66). Berikut dikutipkan mantra atau mamangan yang diperoleh melalui indera pendengaran, kemudian diberikan catatan kaki sebagai bentuk analisis Alfani Daud.

Assalamu alaikum ya Jibril, mu'alaikum salam ya Mika'il, ya Israpil, ya Ijra'il. Assalamu alaikum ya Abu Bekkar, mu'alaikum salam ya Umar, ya Usman, ya Ali. Assalamu alaikum ya Camariah, mu'alaikum salam ya Tambuniah, Uriah. Assalamu alaikum ya Dewa Sukarba,, mu'alaikum salam hai Diang Puracang Suri, nah ini hamba maminta tolong pada sampian [bentuk hormat dari kamu] pada hari ini dan pada detik ini juga, kami dari hamba rakyat jelata di bumi lamah akan mangaturi dahar [harfiah: mempersilahkan makan] kepada sampian, tolong undangkan hamba rakyat sampian, baik yang dekat maupun yang jauh, baik masih kecik maupun sudah besar baik yang berpangkat tinggi maupun yang rendah, undang 
semuanya, karena kami hendak mengaturi dahar (Daud, 1997:353).

Alfani Daud memberikan penjelasan terhadap kata berpangkat, "penulis ragu tentang arti pangkat, apakah dalam arti jabatan seperti lazimnya dalam bahasa Indonesia, ataukah dalam arti kekerabatan, yaitu urutan generasi atau umur, seperti lazimnya dalam bahasa Banjar sehari-hari (seperti yang penulis rasakan)" (Daud, 1997:353). Jadi, rasa bahasa juga dapat digunakan untuk menganalisis suatu data di lapangan.

\section{Reduksi Data}

Reduksi data adalah proses pemilihan, pemustan perhatian pada penyederhanaan, pengabstrakan dan transformasi data kasar yang muncul dari catatan-catatan tertulis di lapangan. Proses ini berlangsung terus menerus selama penelitian berlangsung, bahkan sebelum data benar-benar terkumpul sebagaimana terlihat dari kerangka konseptual penelitian, permasalahan studi, dan pendekatan pengumpulan data yang dipilih peneliti.

Reduksi data meliputi: (1) meringkas data, (2) mengkode, (3) menelusur tema, (4) membuat gugus-gugus. Caranya: seleksi ketat atas data, ringkasan atau uraian singkat, dan menggolongkannya ke dalam pola yang lebih luas.

Meringkas hasil pengumpulan data ke dalam konsep, kategori, dan tema-tema, itulah kegiatan reduksi data, pengumpulan data dan reduksi data saling berinteraksi dengan melalui konklusi dan penyajian data, ia tidak bersifat sekali jadi, tetapi secara bolak balik, perkembangannya bersifat sekuensial dan interaktif, bahkan 
melingkar. Kompleksitas permasalahan bergantung pada ketajaman pisau analisis.

Glasser dan Strauss memunculkan konsep komparasi secara konstan yang mereka maknakan sebagai suatu prosedur komparasi untuk mencermati padu tidaknya data dengan konsep-konsep yang dikembangkan untuk merepresentasikannya, padu tidaknya data dengan kategori-kategori yang dikembangkan, padu atau tidaknya generalisasi atau teori dengan data yang tersedia, serta padu dan tidaknya keseluruhan temuan penelitian itu sendiri dengan kenyataan lapangan yang tersedia. Dengan demikian, komparasi secara konstan tersebut lebih ditempatkan sebagai prosedur mencermati hasil reduksi data atau pengolahan data guna memantapkan keterandalan bangunan konsep, kategori, generalisasi atau teori beserta keseluruhan temuan penelitian itu sendiri sehingga benar-benar padu dengan data maupun dengan kenyataan lapangan.

Selanjutnya Strauss dan Corbin menempatkan konsep komparasi konstan itu sebagai suatu "senjata" yang perlu diterapkan dalam proses pengumpulan data dan analisis data. Berarti juga perlu diterapkan dalam proses pengumpulan data itu sendiri. Karena dalam praktik penelitian kualitatif, kegiatan pengumpulan dan analisis data dapat dikatakan bersenyawa, berlangsung serempak, merupakan suatu kesatuan kegiatan yang tidak dapat dipisahkan. Karenanya, pemikiran dan senjata komparasi secara konstan perlu melekat dalam diri peneliti kualitatif selaku instrument utama suatu penelitian, dan digunakan secara nyata dalam sepanjang proses pengumpulan dan analisis data.

Contoh kasus: peneliti ingin menjelajahi dan melacak kenakalan para siswa di suatu sekolah. Saat observasi awal, misalnya terdengar berbagai komentar guru tentang kenakalan para siswa di dalam 
menaati tata tertib sekolah. Dari komentar tersebut, di benak peneliti mungkin akan muncul serangkaian pertanyaan, misalnya: apakah semua siswa tergolong nakal, suka melanggar aturan tata tertib sekolah? Kalau tidak, lalu yang nakal itu siswa yang mana saja? Mengapa mereka nakal, sementara siswa lainnya tidak? Apakah keseluruhan tata tertib sekolah mereka langgar? Kalau tidak, aturan tata tertib mana saja yang mereka langgar? Mengapa aturan-aturan tertentu yang mereka langgar, sementara aturan lainnya tidak? Kseluruhan merekakah yang melanggar aturan-aturan yang dimaksud? Kalau tidak, siswa mana melanggar aturan yang mana? Mengapa begitu? Selama menjadi siswakah mereka itu melanggar aturan-aturan dimaksud? Kalau tidak, lalu sejak kapan, dan mengapa demikian?

Itu pertanyaan-pertanyaan awal yang mungkin muncul di benak peneliti. Semakinlama kegiatan penjelajahan dan pelacakan berlangsung tentunya semakin banyak data beserta kategori-kategori yang diperoleh sehubungan dengan pertanyaan-pertanyaan tadi dan juga akan memunculkan beberapa pertanyaan baru yang juga menghajatkan penelusuran lebih lanjut, dan begitu seterusnya sampai pada titik jenuh, yaitu hingga ke suatu titik yang tidak memunculkan informasi baru yang diperlukan untuk mendeskripsikan dan menjelaskan fenomena yang tengah di teliti.

Jika prosedur komparasi itu dioperasikan dalam penelitian, data akan semakin bertambah bagaikan bola salju, serta penjelajahan dan pelacakan akan berlangsung laksana kegiatan detektif professional, cerdik dalam membanding-banding dan menghubung-hubungkan berbagai informasi sehingga dari waktu ke waktu kian terungkap gambaran utuh dan rinci dari kasus yang ditangani (Faisal, 2010:7174). 


\section{Penyajian Data}

Penyajian data adalah kegiatan ketika sekumpulan informasi disusun, sehingga memberi kemungkinan akan adanya penarikan kesimpulan dan pengambilan tindakan. Bentuk penyajian data kualitatif dapat berupa teks naratif berbentuk catatan lapangan, matriks, grafik, jaringan, dan bagan. Bentuk-bentuk ini menggabungkan informasi yang tersusun dalam suatu bentuk yang padu dan mudah diraih, sehingga memudahkan untuk melihat apa yang sedang terjadi, apakah kesimpulan sudah tepat atau sebaliknya melakukan analisis kembali.

\section{Penarikan Kesimpulan}

Upaya penarikan kesimpulan dilakukan peneliti secara terusmenerus selama berada di lapangan. Dari permulaan pengumpulan data, peneliti kualitatif mulai mencari arti benda-benda, mencatat keteraturan pola-pola (dalam catatan teori), penjelasan-penjelasan, konfigurasi-konfigurasi yang mungkin, alur sebab akibat, dan proposisi. Kesimpulan-kesimpulan ini ditangani secara longgar, tetap terbuka, dan skeptis, tetapi kesimpulan sudah disediakan. Mula-mula belum jelas, namun kemudian meningkat menjadi lebih rinci dan mengakar dengan kokoh.

Kesimpulan-kesimpulan itu juga diverifikasi selama penelitian berlangsung, dengan cara: (1) memikir ulang selama penulisan, (2) tinjauan ulang catatan lapangan, (3) tinjauan kembali dan tukar pikiran antarteman sejawat untuk mengembangkan kesepakatan intersubjektif, (4) upaya-upaya yang luas untuk menempatkan salinan suatu temuan dalam seperangkat data yang lain.

\section{Simpulan}

Dari penjelasan terdahulu, uraian ini dapat disimpulkan bahwa pengumpulan data bersifat interaktif dengan analisis data. Jadi, 
menganalisis data dalam penelitian kualitatif adalah ketika mengumpulkan data. Sehingga data itu dapat direduksi, reduksi data adalah upaya menyimpulkan data, kemudian memilah-milah data dalam satuan konsep tertentu, kategori tertentu, dan tema tertentu.

Hasil reduksi data diolah sedemikian rupa supaya terlihat sosoknya secara lebih utuh. Ia boleh berbentuk sketsa, sinopsis, matriks, dan bentuk lainnya; itu sangat diperlukan untuk memudahkan pemaparan dan penegasan kesimpulan. Prosesnya, tidak sekali jadi, melainkan berinteraksi secara bolak balik. Baru kemudian data disajikan, dan kemudian disimpulkan dan diverifikasi.

\section{Daftar Pustaka}

Daud, Alfani. 1997. Islam dan Masyarakat Banjar Deskripsi dan Analisa Kebudayaan Banjar. Jakarta: PT RajaGrafindo Persada.

Faisal, Sanapiah. 2010. Pengumpulan dan Analisis Data dalam Penelitian Kualitatif. Dalam Burhan Bungin (editor). Analisis Data Penelitian Kualitatif Pemahaman Filosofis dan Metodologis ke Arah Penguasaan Model Aplikasi (64-79). Jakarta: PT RajaGrafindo Persada.

Miles, Mattew B. dan A. Michael Huberman. 1992. Qualitative Data Analysis: A Sourcebook of New Method. Terjemahan Tjetjep Rohendi Rohidi. Analisis Data Kualitatif: Buku Sumber tentang Metode-metode Baru. Jakarta: Penerbit Universitas Indonesia (UI-PRESS).

Moleong, Lexy J. 2000. Metodologi Penelitian Kualitatif. Bandung: PT Remaja Rosdakarya.

Muhadjir, Noeng. 1998. Metodologi Penelitian Kualitatif Pendekatan Positivistik, Rasionalistik, Phenomenologik, dan Realisme Metaphisik Telaah Studi Teks dan Penelitian Agama

Sugiono. 2007. Metode Penelitian Bisnis. Bandung: Alfabeta 